\title{
Analisis Kasus Prita Mulyasari Dalam Putusan Peninjiauan Kembali No. 225 Pk/Pid.Sus/2011
}

\author{
Nerissa Arviana ${ }^{1}$, Sari Mandiana ${ }^{2}$, Jusup Jacobus Setyabudhi ${ }^{3}$ \\ ${ }^{1}$ Program Studi Magister Hukum, Universitas Pelita Harapan Kampus Surabaya, Jl. Ahmad Yani, Surabaya, 60234 \\ E-mail: nerissaarviana10@gmail.com \\ ${ }^{2}$ Program Studi Magister Hukum, Universitas Pelita Harapan Kampus Surabaya, Jl. Ahmad Yani, Surabaya, 60234 \\ E-mail: - \\ ${ }^{3}$ Program Studi Magister Hukum, Universitas Pelita Harapan Kampus Surabaya, Jl. Ahmad Yani, Surabaya, 60234 \\ E-mail: -
}

\begin{abstract}
Social media are growing so rapidly now, besides having a positive impact on society, it also has negative impacts such as hoaxes, pornography, and defamation. Some cases that are closely related to social media are criminal defamation in violation of the Information and Electronic Transactions Law, as experienced by Prita Mulyasari, a case that was initiated by sending a complaint email for Omni Hospital to her friends, so She was charged violating No. 11 of Information and Electronic Transactions Law year 2008, in this study the author uses the Doctrinal or Normative Juridical research methodology by discussing court decision No. 225 PK / PID. SUS / 2011 where in this case Prita Mulyasari was dismissed by the Tangerang District Court, but was found guilty at the Supreme Court level and finally was released free at the Judicial Review level.
\end{abstract}

Keywords—: Prita Mulyasari; RS. Omni; Information and Electronic Transaction Law.

\section{LATAR BELAKANG MASALAH}

Indonesia, dari data Webershandwick, memiliki 65 juta pengguna Facebook aktif, dan 33 juta pengguna aktif setiap harinya, 55 juta pengguna menggunakan ponsel untuk mengakses per bulan dan 28 juta menggunakan ponsel untuk mengakses per harinya. Beberapa kasus yang berkaitan dengan Undang-Undang (yang selanjutnya dsingkat UU) Informasi dan Transaksi Elektronik (yang selanjutnya disingkat ITE), yang pernah terjadi di Indonesia misalnya kasus Prita Mulyasari dan kasus Baiq Nuril yang menyita perhatian publik.

Kasus Prita Mulyasari berawal saat Prita berobat ke rumah sakit (RS) Omni Jakarta, Prita mengalami keluhan demam tinggi dan rumah sakit melakukan uji laboratorium (uji lab) darah pada tanggal 7 Agustus 2008. Hasil uji lab tromobosit darah Prita adalah 27.000 (normal 200.000). Prita kemudian mendapatkan beberapa tindakan medis, namun pada tanggal 8 Agustus 2008 terjadi revisi hasil uji lab tersebut, trombosit tertulis 181.000. Tanggal 11 Agustus 2008 Prita memutuskan keluar dari RS Omni, dan meminta hasil lab darahnya, namun yang didapat hanya informasi thrombosit 181.000. Pasalnya, berdasar hasil lab thrombosit 27.000 itulah Prita akhirnya dirawat inap. Pihak rumah sakit omni mengatakan bahwa hal tersebut tidak diperkenankan karena hasilnya memang tidak valid.

Di rumah sakit yang baru, Prita dimasukkan ke dalam ruang isolasi karena dia terserang virus yang menular. Prita kemudian mengirimkan email berisi keluhan atas pelayanan yang diterimanya dari pihak RS Omni ke customer_care@banksinarmas.com dan ke kerabatnya dangan judul "Penipuan RS Omni Internasional Alam Sutra". Prita Mulyasari mengirimkan email tersebut ke sejumlah orang.

Pada tanggal 5 September 2008 RS Omni Internasional mengajukan laporan ke Direktorat Reserse Kriminal Khusus (Direskrimsus). RS Omni, selain mengajukan laporan ke kepolisian, juga mengajukan gugatan ke pengadilan. Penelitian ini hanya meneliti perkara pidananya saja, tidak meneliti perkara perdatanya.

Jaksa Penuntut Umum (JPU) dalam dakwaannya, mendakwa Prita dengan dakwaan alternatif. Pertama melanggar Pasal 45 Ayat (1) jo. Pasal 27 Ayat (3) Undang-Undang Nomor 11 Tahun 2008 tentang Informasi dan Transaksi Elektronik (yang selanjutnya akan disebut UU ITE), kedua melanggar Pasal 310 Ayat (2) Kitab Undang-Undang Hukum Pidana (yang selanjutnya disingkat KUHP), dan yang ketiga melanggar Pasal 311 Ayat (1) KUHP.

Prita Mulyasari sempat diputus tidak bersalah oleh putusan PN Tanggerang. Namun kemudian putusan tersebut dibatalkan di tingkat Kasasi, hingga akhirnya pada tingkat Peninjauan Kembali yaitu putusan no. 225 PK/PID.SUS/2011 tanggal 17 September 2012 Prita Mulyasari diputus tak bersalah dan bebas dari semua dakwaan dan dipulihkan nama baik, harkat dan kedudukannya. ${ }^{1}$

Berdasarkan latar belakang diatas penulis tertarik untuk mengemukakan rumusan masalah sebagai berikut:

\footnotetext{
${ }^{1}$ Kronologi Kasus Prita Mulyasari https://www.kompasiana.com/iskandarjet/54fd5ee9a33311021750fb34/kronologi-kasus-prita-mulyasari?page=all [diakses 17 desember 2018]
} 
a. Putusan manakah diantara Putusan PN Tanggerang, Putusan Mahkamah Agung, dan Putusan Peninjauan Kembali yang tepat dan benar dalam kasus Prita Mulyasari menurut Pasal 27 Ayat 3 UU ITE?

b. Adakah akibat hukum atau konsekuensi hukum dengan adanya putusan bebas melalui Putusan PK?

\section{METODE PENELITIAN}

Pendekatan Masalah dalam penelitian ini menggunakan Statute Approach, Doctrinal Approach, dan Case Approach. Statute Approach adalah pendekatan yang dilakukan melalui peraturan perundang - undangan. Doctrinal Approach adalah adalah pendekatan yang dilakukan dengan melihat pandangan dan doktrin para sarjana di bidang hukum. Case Approach adalah pendekatan yang digunakan melalui substansi putusan PN Tangerang no. 1269/PID.B/2009/PN.TNG, Putusan MA no. 822 K/Pid.Sus/2010, putusan PK no. 225 PK/PID.SUS/2011, dan Novum Putusan no.300 K/PDT/2010.

\section{III.HASIL PENELITIAN DAN PEMBAHASAN}

\section{A. Pencemaran Nama Baik Menurut Pasal 27 Ayat 3 UU ITE}

Pencemaran nama baik diatur dalam Pasal 310 sampai dengan Pasal 321 KUHP. Khusus tentang pencemaran diatur dalam Pasal 310 KUHP. Ketentuan Pasal 311 Ayat 1 KUHP memiliki hubungan erat dengan Pasal 310 Ayat 3 KUHP, dikatakan demikian karena apabila pelaku pencemaran nama baik diperolehkan untuk membuktikan apakah yang ia tuduhkan pada seseorang itu benar, namun tidak dapat membuktikannya, maka pelaku pencemaran nama baik tersebut disebut sebagai pelaku pemfitnahan. Menurut Pasal 313 KUHP dan Pasal 319 KUHP pencemaran nama baik atau penghinaan maupun pemfitnahan termasuk dalam delik aduan, tersirat dalam kata "jika hal yang dituduhkan hanya dapat dituntut atas pengaduan".

Perihal pencemaran nama baik dalam UU ITE tercantum dalam bab 7 tentang perbuatan yang dilarang yang meliputi Pasal 27 s/d Pasal 37 UU ITE. Menilik Pasal 27 Ayat (3) dikatakan setiap orang dengan "sengaja mendistribusikan.... membuat dapat diaksesnya Informasi Elektronik... yang memiliki muatan penghinaan atau pencemaran nama baik". Pasal ini mencantumkan tindak pidana yang dikenal dalam KUHP dengan penghinaan dan/atau pencemaran nama baik sebagaimana yang diatur dalam Pasal 310 dan 311 KUHP. Frasa "muatan penghinaan dan/atau pencemaran nama baik" tidak dijelaskan dalam UU ITE, hal ini menunjukkan bahwa tindak pidana pencemaran nama baik yaitu Pasal 27 Ayat 3 merupakan bagian khusus (lex specialis) dari penghinaan "bleediging" BAB XVI Buku II KUHP. ${ }^{2}$

Putusan no. 1269/PID.B/2009/PN.TNG tanggal 29 Desember 2009 di PN Tanggerang, Prita Mulyasari didakwa dengan Pasal 45 Ayat (1) jo. Pasal 27 Ayat (3) UU ITE, Pasal 310 Ayat (2) KUHP, atau Pasal 311 Ayat (1) KUHP. Berdasarkan pertimbangan hukum PN Tangerang, dimana perbuatan Prita tidak memenuhi unsur ketiga dari Pasal 27 Ayat (3) UU ITE yaitu mendistribusikan dan/atau mentransmisikan dan/atau membuat dapat diaksesnya informasi elektronik dan/atau dokumen elektronik yang memiliki muatan penghinaan dan/atau pencemaran nama baik", karena berdasarkan pertimbangan hakim bahwa dokumen atau email yang dikirimkan tersebut tidak bermuatan penghinaan atau pencemaran nama baik, melainkan adalah kritikan dan demi kepentingan umum agar masyarakat terhindar dari praktek rumah sakit dan/atau dokter yang memberikan pelayanan medis yang baik terhadap orang sedang sakit yang mengharapkan sembuh dari penyakit ${ }^{3}$, Prita Mulyasari dinyatakan tidak terbukti secara sah dan meyakinkan bersalah melakukan tindak pidana.

JPU mengajukan Kasasi ke MA, dalam putusannya no. 822 K/Pid.Sus/2010 pertimbangan hukum MA menyatakan:

a. Prita Mulyasari merupakan putusan bebas tidak murni (verkapte vrijspraak)

b. Perbuatan Prita Mulyasari telah memasuki pokok perkara dan menolak pemohonon kasasi dari Prita Mulyasari.

Terdapat perbedaan pendapat (dissenting opinion) dari anggota majelis yang memeriksa dan memutus perkara kasus Prita Mulyasasi, dan berdasarkan Pasal 30 Ayat 3 Undang-Undang No. 14 Tahun 1985 sebagaimana diubah dengan Undang-Undang No.5 tahun 2004 dan perubahan kedua yaitu Undang-Undang no. 3 Tahun 2009, hakim mengabulkan permohonan kasasi dari JPU dan menolak permohonan kasasi yang diajukan oleh Prita Mulyasari.

Berdasarkan pertimbangan hukum tersebut MA memutuskan Prita Mulyasari terbukti secara sah dan meyakinkan bersalah melakukan tindak pidana "dengan sengaja dan tanpa hak mendistribusikan dan/atau mentransmisikan dan/atau membuat dapat diaksesnya informasi elektronik dan/atau dokumen elektronik yang memiliki muatan penghinaan dan/atau pencemaran nama baik".

Prita Mulyasari mengajukan PK pada tanggal 1 Agustus 2011 yaitu putusan no. 225 PK/PID.SUS/2011. Pertimbangan hukum pada tingkat PK ini adalah:

1. Adanya novum baru, yaitu putusan perdata no.300 K/PDT/2010 putusan dalam tingkat kasasi yang diajukan oleh Prita Mulyasari.

2. Adanya kekeliruan nyata dari hakim karena perilaku Prita Mulyasari sama sekali tidak memiliki tujuan untuk melakukan pencemaran, dan perbuatan Prita Mulyasari yang melawan hukum tidak dapat dibuktikan. ${ }^{4}$

Berdasarkan pertimbangan hukum tersebut, Prita Mulyasari dinyatakan tidak terbukti secara sah dan meyakinkan bersalah melakukan tindak pidana.

\footnotetext{
${ }^{2}$ Adami Chazawi dan Ardi Ferdian. Tindak Pidana Informasi dan Transaksi Elektronik, (Malang: Media Nusa Creative, 2015 ). hlm. 73.

${ }^{3}$ Putusan no. 1269/PID.B/2009/PN.TNG. hlm. 62.

${ }^{4}$ Putusan No. 225 PK/PID.SUS/2011. hlm. 39
} 


\section{B. Konsekuensi Hukum Dengan Keberatan Putusan Bebas}

Putusan bebas (vrijspraak) atau acquittal adalah dimana terdakwa tidak dipidana atau tidak menjalani hukuman karena hasil pemeriksaan dipersidangan terdakwa tidak terbukti secarah sah dan meyakunkan menurut hukum, atau secara yuridis hakim berpendapat ketentuan minimum pembuktian dan keyakinan hakim yang berdasar pada Pasal 183 KUHAP tidak terbukti. ${ }^{5}$

Penahanan secara tidak sah merupakan tindakan perampasan kemerdekaan bergerak bagi seseorang. ${ }^{6}$ Dalam hukum acara pidana lama tidak diatur mengenai kerugian, ketentuan ganti kerugian yang disebabkan oleh penangkapan, penahanan yang tidak sah, hal itu tercantum pula dalam International Covenant on Civil and Political Rights pada Pasal 9 yang berbunyi "seseorang yang telah menjadi korban penangkapan atau penahanan tidak sah akan mendapatkan hak menuntut ganti kerugian". 7 Hak terdakwa setelah diputus bebas adalah mendapatkan ganti kerugian dan rehabilitasi yang diatur dalam diatur dalam Penjelasan Umum Poin 3 huruf d KUHP.

Putusan PK no. 225 PK/PID.SUS/2011 yang menyatakan Prita Mulyasari bebas tidak terbukti melakukan tindak pidana pencemaran nama baik yang melanggar Pasal 45 Ayat (1) jo. Pasal 27 Ayat (3) UU ITE, atau Pasal 310 Ayat (2) KUHP, atau Pasal 311 Ayat (1) KUHP memiliki konsekuensi Prita Mulyasari dapat menggugat ganti rugi terhadap pihak Penggugat yaitu RS Omni. Demikian halnya dengan ketentuan Pasal 314 Ayat (2) KUHP yang berbunyi "Jika dia dengan putusan hakim yang menjadi tetap dibebaskan dari hal yang dituduhkan, maka putusan itu dipandang sebagai bukti sempurna bahwa hal yang dituduhkan tidak benar", atas dasar kedua Pasal tersebut di atas, maka Prita Mulyasari berhak menuntut ganti rugi pada RS Omni atas penderitaan dan kerugian materiil maupun immaterial Prita Mulyasari menjadi pesakitan.

Berdasarkan ketentuan Pasal tersebut dan putusan PK no. 225 PK/PID.SUS/2011 yang mendapatkan pemulihan kehormatan nama baik, maka Prita Mulyasari dapat menggugat ganti rugi berdasarkan perbuatan melawan hukum.Berdasarkan ketentuan Pasal 1372 BW tentang mendapatkan penggantian kerugian serta pemulihan kehormatan nama baik, hal ini diperkuat dengan Pasal 1376 BW yang berbunyi "Tuntutan perdata tentang penghinaan, tak dapat dikabulkan jika tidak ternyata adanya maksud untuk menghina. Maksud untuk menghina itu tidak dianggap ada, jika si pembuat nyata-nyata telah berbuat untuk kepentingan umum atau untuk pembelaan darurat terhadap dirinya."

Berdasarkan ketentuan Pasal 1377 BW yang berbunyi "Begitu pula tuntutan perdata itu tidak dapat dikabulkan, jika si terhina dengan suatu putusan Hakim yang telah memperoleh kekuatan multlak telah dipersalahkan tentang melakukan perbuatan yang dituduhkan kepadanya". Tuntutan ganti rugi yang dapat ditujukan pada RS Omni oleh Prita Mulyasari harus disertai dengan putusan pidana dari hakim yang telah memperoleh kekuatan hukum tetap, dalam hal ini adalah putusan PK no. 225 PK/PID.SUS/2011.

Namun segala upaya hukum yang diberikan bagi Prita Mulyasari sebagai konsekuensi diputus bebas atas dakwaan melanggar Pasal Pasal 45 Ayat (1) jo. Pasal 27 Ayat (3) UU ITE tidak ditempuh. Berdasarkan Pasal 1380 BW yang berbunyi "Tuntutan dalam perkara penghinaan gugur dengan lewatnya waktu satu tahun, terhitung mulai hari dilakukannya perbuatan dan diketahuinya perbuatan itu oleh si penggugat". Prita tidak dapat melakukan tuntutan ganti rugi terhadap RS Omni karena telah melewati batas waktu yang telah diatur dalam Pasal $1380 \mathrm{BW}$.

\section{IV.KESIMPULAN}

Berdasarkan pembahasan diatas penulis setuju dengan putusan PN no. 1269/PID.B/2009/PN.TNG yang diputus bebas, serta Putusan PK no. 225 PK/PID.SUS/2011 dalam amar putusannya sesuai dengan novum yang didasarkan pada putusan perdata no. $300 \mathrm{~K} / \mathrm{PDT} / 2010$ yang dinyatakan bebas, dan tidak terbukti secara sah dan meyakinkan menurut hukum melakukan dalam tindak pidana pencemaran nama baik RS Omni. Penulis sependapat dengan pertimbangan hakim Pengadilan Negeri Tangerang dan hakim tingkat Penijauan Kembali atas isi email Prita Mulyasari yang sebenarnya tidak memiliki unsur penghinaan atau pencemaran nama baik, melainkan berisi sebuah keluhan atau kritikan atas layanan dari RS Omni yang diterima oleh Prita Mulyasari.

Dengan adanya putusan bebas pada putusan PK no. 225 PK/PID.SUS/2011, Prita Mulyasari memperoleh pemulihkan kehormatan dan nama baiknya seperti yang tertuang dalam amar putusannya "Memulihkan hak terpidana dalam kemampuan, kedudukan dan harkat serta martabatnya", atas dasar tersebut Prita Mulyasari dapat mengajukan gugatan ganti rugi kepada RS Omni atas dasar perbuatan melawan hukum. Mengingat Pasal 1380 BW gugatan ganti rugi yang diajukan Prita Mulyasari memiliki jangka waktu satu tahun. Mengingat setelah lewat jangka waktu 1 tahun telah berlalu, maka Prita Mulyasari tidak dapat melakukan gugatan ganti rugi kepada RS Omni

\footnotetext{
${ }^{5}$ Lilik Mulyadi Lilik Mulyadi. Hukum Acara Pidana (Bandung: PT Citra Adiya Bakti, 2007) hlm. 150.

${ }^{6}$ Ruslan Renggong. Hukum Acara Pidana - Memahami Perlindungan Ham Dalam Proses Penahanan di Indonesia (Jakarta: Prenadamedia Group, 2014) hlm. 142.

${ }^{7}$ Andi Hamzah. Hukum Acara Pidana Indonesia (Jakarta: Sinar Grafika, 2009) hlm. 198
} 
Website : http://yustisia.unmermadiun.ac.id/index.php/yustisia

\section{DAFTAR PUSTAKA}

\section{A. Buku}

Chazawi, Adami dan Ardi Ferdian. Tindak Pidana Informasi dan Transaksi Elektronik, (Malang: Media Nusa Creative, 2015)

Marpaung, Leden. Proses Penanganan Perkara Pidana. (Jakarta: Sinar Grafika, 1992)

Renggong, Ruslan. Hukum Acara Pidana - Memahami Perlindungan Ham Dalam Proses Penahanan di Indonesia (Jakarta: Prenadamedia Group, 2014)

\section{B. Jurnal}

Susilowati, Nani. Skripsi: Analisis Tentang Kasasi Terhadap Putusan Lepas Dari Segala Tuntutan Hukum Oleh Jaksa Penuntut Umum (Universitas Sebelas Maret Surakarta, 2008)

\section{Website}

Iskandarjet, Kronologi Kasus Prita Mulyasari (https://www.kompasiana.com/iskandarjet/54fd5ee9a33311021750fb34/kronologi-kasus-pritamulyasari?page=all) (diakses 17 desember 2018)

\section{Peraturan Perundang-undangan}

Hukum Acara Pidana Undang-Undang No. 8 Tahun 1981 Tanggal 31 Desember 1981

Kitab Undang-Undang Hukum Pidana (Staatsblad Tahun 1915 nomor 732 dan mulai berlaku sejak tanggal 1 Januari 1918)

Undang-Undang No. 11 Tahun 2008 Tentang Informasi dan Transaksi Elektronik dan Perubahannya no. 19 tahun 2016. Undang-Undang Nomor 11 Tahun 2008 tentang Informasi dan Transaksi Elektronik (Lembaran Negara Republik Indonesia Tahun 2008 Nomor 58, Tambahan Lembaran Negara Republik Indonesia Nomor 4843)

Putusan Pengadilan Negeri Tangerang no. 1269/PID.B/2009/PN.TNG, perkara Prita Mulyasari, 6 Januari 2010

Putusan Mahkamah Agung no. 822 K/Pid.Sus/2010, perkara Prita Mulyasari, 30 Juni 2011

Putusan Peninjauan Kembali no. 225 PK/PID.SUS/2011, perkara Prita Mulyasari 17 September 2012

Novum Putusan no.300 K/PDT/2010, perkara Prita Mulyasari 28 September 2010

Peraturan Pemerintah Republik Indonesia Nomor 92 Tahun 2015 Tentang Perubahan Kedua Atas Peraturan Pemerintah Nomor 27 Tahun 1983 Tentang Pelaksanaan Kitab Undang-Undang Hukum Acara Pidana 